\title{
Does rectal application of Red-Ginseng have an effect on colorectal anastomosis healing? An experimental study
}

\section{Rektal yoldan uygulanan Red-Ginseng'in kolorektal anastomoz iyileşmesi üzerinde etkisi var mıdır? Bir deneysel çalıșma}

\author{
Abdullah Şenlikçi ${ }^{1}$, Koray Koşmaz ${ }^{1}$, Abdullah Durhan ${ }^{1}$, Marlen Süleyman ${ }^{1}$, Yusuf Murat Bağ ${ }^{2}$, Mevlüt Recep Pekcici ${ }^{1}$, \\ Mehmet Şenes ${ }^{3}$, İknur Alkan Kusabbi ${ }^{3}$, Özlem Tanas Işskçı ${ }^{4}$, Yılmaz Ünal ${ }^{1}$, Sema Hücümenoğlu ${ }^{4}$
}

\section{Abstract}

Aim: To evaluate the possible effects of red-ginseng on colon anastomosis healing in an experimental rat model. Methods: In Group 1 (sham), laparotomy and colonic mobilization were performed. Colonic transection and anastomosis were performed to Groups 2 and 3. In Group 2 (control), $2 \mathrm{ml}$ of saline was administered rectally to all rats for 10 days. Group 3 (drug group) rats were given $2.5 \mathrm{gr} / \mathrm{kg} \mathrm{ml}$ red ginseng extract rectally for 10 days. Results: The rats in the sham group had the highest bursting pressure and the rats in the red ginseng group had higher bursting pressure than in the control group $(\mathrm{p}<0.05)$. A significant difference was observed only for the total SH level between the control group and the red ginseng group $(p=0.008)$. The red ginseng group had the highest scores for all parameters in the histopathological evaluation and the differences were significan compared to both the sham group and the control group.

Conclusion: Rectally administered red-ginseng significantly increased wound healing parameters and increased anastomotic burst pressure. This is the first study in the literature on the beneficial effects of red-ginseng on colorectal anastomoses.

Keywords: Red-ginseng, anastomosis, antioxidant, rat
1 University of Health Sciences, Ankara Education and Research Hospital, Department of General Surgery, Ankara, Turkey.

2 University of Health Sciences, Van Education and Research Hospital, Department of General Surgery, Ankara, Turkey.

3 University of Health Sciences, Ankara Education and Research Hospital, Department of Biochemistry, Ankara, Turkey.

4 University of Health Sciences, Ankara Education and Research Hospital, Department of Pathology, Ankara, Turkey.

AS: $0000-0002-4321-4004$

KK: 0000-0003-2111-3162

AD: 0000-0002-5622-9678 MS: 0000-0001-6979-4150

YMB: 0000-0002-0159-9356

MRP: 0000-0002-5566-8134

MS: 0000-0002-7924-5478

IAK: 0000-0003-0000-1196

OTI: 0000-0003-0864-3425

YU: 0000-0001-9712-5827

SH: 0000-0002-6898-4101

Ethics Committee Approval: This study was approved by the Animal Experiments Local Ethics Committee (Ankara Education and Research Hospital Animal Experiments Ethics Committee; Approval date: 27/01/2021; Approval No: 64). Etik Kurul Onayı: Bu çalışma Hayvan Deneyleri Yerel Etik Kurulu tarafından onaylanmıștır (Ankara Eğitim ve Araştırma Hastanesi Hayvan Deneyleri Etik Kurulu; Onay tarihi: 27/01/2021; Onay No: 68)

Conflict of Interest: No conflict of interest was declared by the authors.

Financial Disclosure: The authors declared that this case has received no financial support.

Geliş Tarihi / Received: 16.08.2021

Kabul Tarihi / Accepted: 01.12.2021

Yayın Tarihi / Published: 09.12.2021

Sorumlu yazar / Corresponding author:

Abdullah Senlikci

Adres/Address: Ankara Eğitim ve Araştırma

Hastanesi Genel Cerrahi Kliniği Ankara, Turkey.

e-mail: asenlikci94@hotmail.com

Tel/Phone: +90 5056420205

Copyright (C) ACEM 


\section{Introduction}

Anastomotic leakage after colon resection and anastomosis is a serious problem for surgeons. Colorectal anastomotic leakage can cause devastating acute and long-term consequences, such as the need for additional intervention, prolonged hospital stay, and higher morbidity and mortality rates [1]. For many years, studies have been conducted not only for the development of new surgical techniques but also for the evaluation of locally or systemically applied products to prevent anastomotic leakage, but no method that is still widely used has been found as yet [2].

Red ginseng is the boiled root of Panax ginseng CA Meyer and has a long history of use in East Asia as a medicinal herb. Recent studies have reported various effects of red ginseng, including antioxidant, antitumor, antimutagenic, antidiabetic, and immunomodulatory activities [3]. Studies have shown that red ginseng has positive effects on wound healing [4].

Knowing the positive effect of red ginseng on wound healing, the aim of this study was to evaluate the effect of rectal application of red ginseng on rats with colorectal anastomosis.

\section{Material and methods}

All procedures in this experimental study were applied in accordance with the National Laboratory Animals Use and Care Guidelines and approved by the Animal Ethics Committee of Ankara Training and Research Hospital (date of approval: 27.01.2021, protocol number:0064).

\section{Animals and Experimental Study Procedure}

The study included a total of 30 female WistarAlbino rats with a mean weight of $230 \pm 18$ grams. All rats were fed with commercial rat chow and kept in wire cages under standard laboratory conditions. Food was withdrawn from the rats 12 hours before anesthesia and water 2 hours before. The anesthesia and surgical procedure were performed by the same team under sterile conditions. Before the procedure was started, all rats were anesthetized intramuscularly with $50 \mathrm{mg} / \mathrm{kg}$ ketamine hydrochloride and $5 \mathrm{mg} / \mathrm{kg}$ Xylazine. Enteral and parenteral antibiotics were not given during the study.

The 30 rats were randomly separated into 3 groups of 10. In Group 1 (sham) laparotomy and colonic mobilization were performed (Figure 1). Colonic transection and anastomosis were performed in Group 2 and Group 3 (Figure 2,3). The colonic transection was performed in the descending colon, in a $2 \mathrm{~cm}$ area kept $3 \mathrm{~cm}$ above the peritoneal reflection. Following the transection, end-to-end anastomosis was applied with 5-0 prolene to all rats by the same physician. The abdominal layers were closed with 3-0 silk continuous sutures. In Group 2 (control), $2 \mathrm{ml}$ of saline was administered rectally by feeding tube (6 F) for 10 days. In Group 3 (drug group), $2.5 \mathrm{~g} / \mathrm{kg} \mathrm{ml}$ of red ginseng extract was administered rectally via a feeding tube (6 F) for 10 days. Prior to the daily administration of saline or red ginseng, anaesthesia of $8 \mathrm{mg} / \mathrm{kg}$ ketamine hydrochloride was administered intramuscularly. The rats were placed in the Trendelenburg position and the feeding tube was advanced $5 \mathrm{~cm}$ into the anal canal and saline or red ginseng extract was administered.

On the postoperative 11th day, all the rats were sacrificed using high-dose anesthetic. Then, a U-shaped incision was made and the anastomosed segments were resected. In Group 1, the colon segment of the same region was resected. The anastomotic bursting pressure of all the specimens in the 3 groups was measured. After division into 2 parts longitudinally and histopathologically, the tissue malondialdehyde (MDA), total sulfhydryl (t-SH) and catalase (CAT) levels were measured.

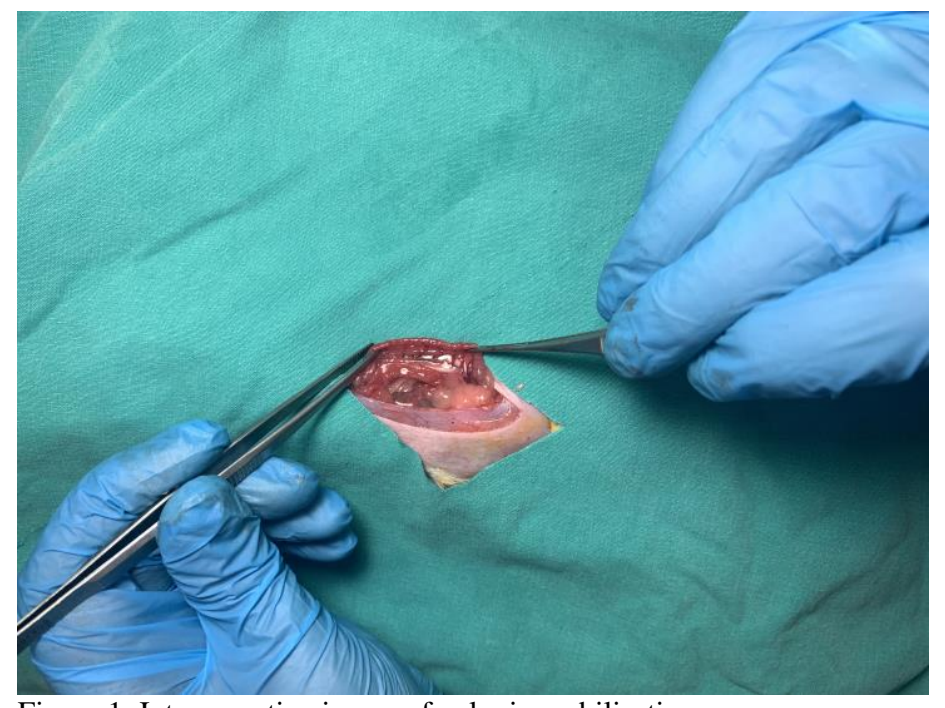

Figure 1. Intraoperative image of colonic mobilisation.

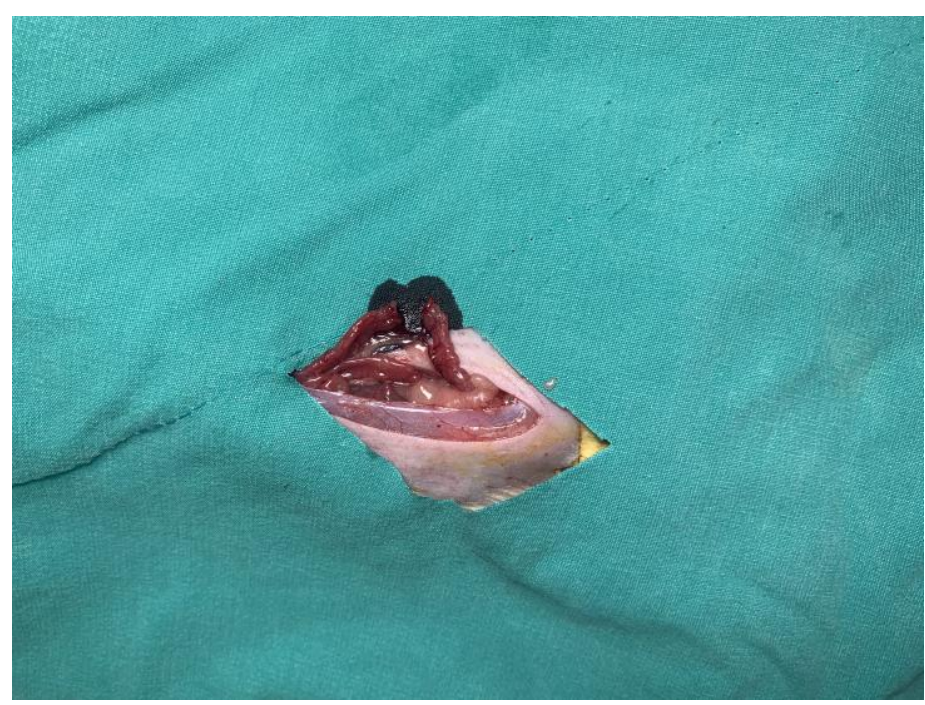

Figure 2. Intraoperative image of colonic transection.

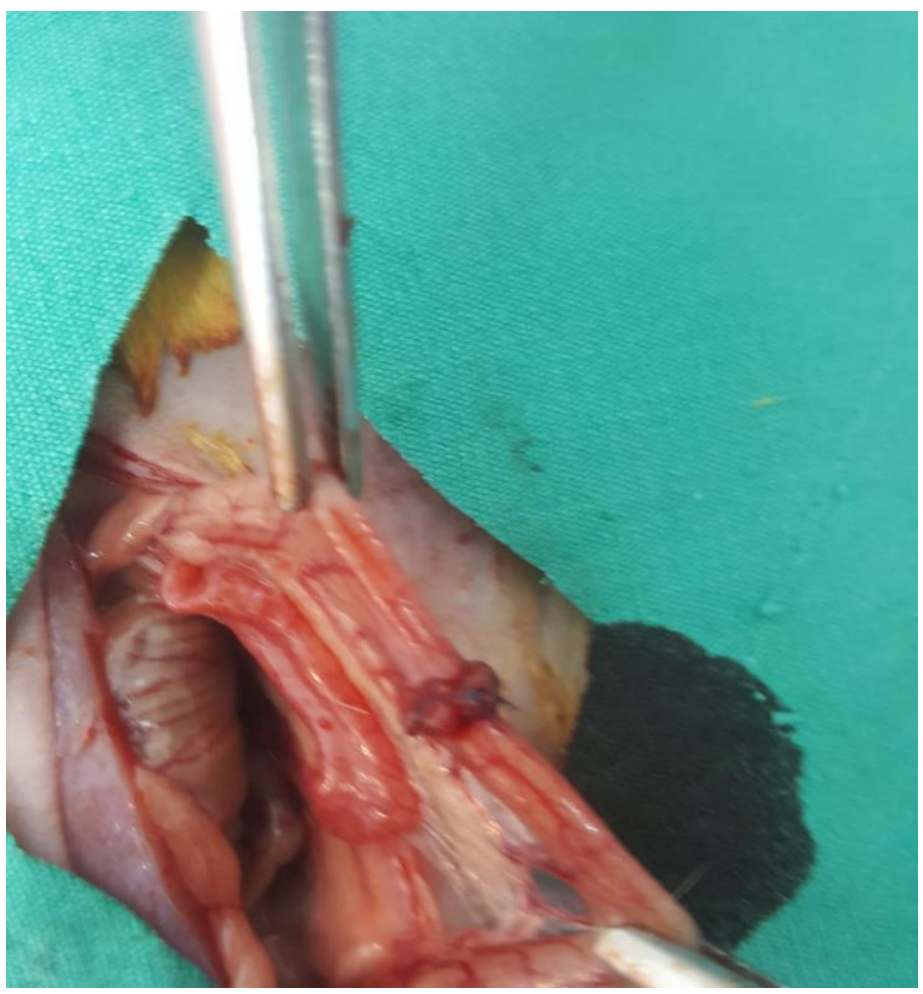

Figure 3. Intraoperative image of colonic anastomosis. 


\section{Anastomotic bursting pressure measurement}

Excision was made to include the surrounding tissue 2.5 $\mathrm{cm}$ proximal and distal to the anastomosis. The distal of the anastomosis was tied with a 3-0 silk suture. A plastic catheter was placed on the unattached side and tied with 3-0 silk suture to prevent air leakage. The plastic catheter was connected to a pump connected to a barometer. The bowel segment was placed in a container full of water. The pump pressure was increased, and when air bubbles were observed, this pressure was considered to be the anastomotic bursting pressure, and was recorded in $\mathrm{mmHg}$.

Measurement of malondialdehyde (MDA), total sulfhydryl (t-SH) and catalase (CAT) levels

The parameters of oxidative stress were evaluated in the Biochemistry Department of Ankara Training and Research Hospital. Liver tissues were kept at $-80^{\circ} \mathrm{C}$ until the day of the analysis. The malondialdehyde (MDA), total sulfhydryl (t-SH) and catalase (CAT) levels were determined.

Tissues were homogenized in phosphate buffer for MDA, t-SH and CAT measurements.

The levels of MDA were measured using the fluorometric method, as described by Wasowicz et al. [5] Following the reaction that occurs between thiobarbituric acid (TBA) and MDA, the reaction product was isolated in butanol. Then spectrofluorometric measurement was made at a wave length of $547 \mathrm{~nm}$ for emission and $525 \mathrm{~nm}$ for excitation. The standard was 0 to $5 \mu \mathrm{mol} / \mathrm{L} \quad 1,1^{\prime}, 3,3^{\prime}$ tetraethoxypropane solution. $50 \mu \mathrm{L}$ homogenate was introduced into $10 \mathrm{ml}$ glass tubes, each containing $1 \mathrm{ml}$ of distilled water in order to measure MDA levels in tissue. A $1 \mathrm{~mL}$ solution containing $29 \mathrm{mmol} / \mathrm{L}$ TBA was added to acetic acid and mixed. The samples were then exposed to heat of between $95^{\circ}$ and $100^{\circ} \mathrm{C}$ for a period of 1 hour using a water bath. After cooling the heated samples, they were mixed with $25 \mu \mathrm{L}$ of $5 \mathrm{~mol} / \mathrm{L}$ hydrochloric acid (HCL) and agitation was used for a period of 5 min to extract the mixture of the reaction using $3.5 \mathrm{~mL}$-butanol. The butanol phase was separated through centrifugation for $10 \mathrm{~min}$ at $1500 \mathrm{~g}$, then a fluorometer (HITACHI F-2500) was used to measure the fluorescence in the butanol extract at $547 \mathrm{~nm}$ and $525 \mathrm{~nm}$ wavelengths for emission and excitation, respectively. The levels of MDA were shown as nmol/g protein.

Determination of CAT levels was made with spectrophotometric measurement, as defined by Hadwan [6]. The test is for biological samples and depends on the rapid formation of a stable and colored carbonato-cobaltate (III) complex. The method is based on the conversion of cobalt (II) to cobalt (III) by hydrogen peroxide in biological tissues in the presence of bicarbonate. First, the samples were incubated with hydrogen peroxide solution for 2 minutes. The working solution containing the cobalt-bicarbonate reagent was then added. This reagent evaluates unreacted hydrogen peroxide. CAT activity is always directly proportional to the rate of decomposition of hydrogen peroxide. Hydrogen peroxide acts as oxidizing cobalt (II) to cobalt (III) in the presence of bicarbonate ions; this process ends with the production of a carbonato-cobaltate (III) complex ([Co (CO3) 3] Co). The final product formed has two maximum absorbance wavelengths: $440 \mathrm{~nm}$ and $640 \mathrm{~nm}$. The $440 \mathrm{~nm}$ wavelength was used to evaluate CAT activity. The value of CAT activity was determined using the first order reaction rate constant as $\mathrm{kU}$. CAT activity level was reported as $\mathrm{kU} / \mathrm{g}$ protein.

The t-SH measurement was performed according to the principle described by Taylan et al, in which this method was applied by adapting the Ellman reaction to the microplate method [7]. Methanolic 5,5'-dithiobis (2-nitrobenzoic acid) (DTNB) solution, which reacts with sulfhydryl groups, was used in this study. The reaction products were measured using a multimeasurement mode microplate reader containing the monochromator. The measurement was carried out at $412 \mathrm{~nm}$. $200 \mu \mathrm{L}$ of Tris buffer $(0.25 \mathrm{M}$ Tris- $\mathrm{HCl}, \mathrm{pH} 8.2$ containing 20 mM EDTA) was pipetted and $25 \mu \mathrm{L}$ of homogenate was added. $10 \mu \mathrm{L}$ of DTNB reagent ( $4 \mathrm{mg} / \mathrm{mL}$ in methanol) was added to each well and incubated for 15 minutes at room temperature, then the absorbance of yellow 5-thio-2-nitrobenzoic acid (TNB) at $412 \mathrm{~nm}$ (A2) was measured against blank (A1). Glutathione standards were also tested under the same conditions, and the curve was generated by linear regression analysis. The content of the t-SH group in the samples corresponding to the net absorbance (A2-A1) was calculated from the standard curve generated using reduced glutathione (GSH) (between 0 and 450 $\mu \mathrm{M})$. $\mathrm{t}-\mathrm{SH}$ levels are given as $\mu \mathrm{mol} / \mathrm{gr}$ protein.

\section{Histological Evaluation}

The anastomosis line was incised longitudionally and fixed in $4 \%$ formaldehyde solution and embedded in paraffin with a routine procedure. Sections $3 \mathrm{~mm}$ in thickness were cut from tissue blocks and stained with hemotoxylin and eosin. The anastomosis line was graded in a blinded fashion using the Ehrlich and Hunt numerical scale (8) from 0 to 4 , as modified by Philips et al (9). Inflamatory cell infiltration, fibroblast activity, neo-angiogenesis and collagen deposition were graded from 0 to 4 as follows: 0:no evidence, 1: occasional evidence, 2: light scattering, 3: abundant evidence and 4: confluent cells or fibers (Figure 4-6).

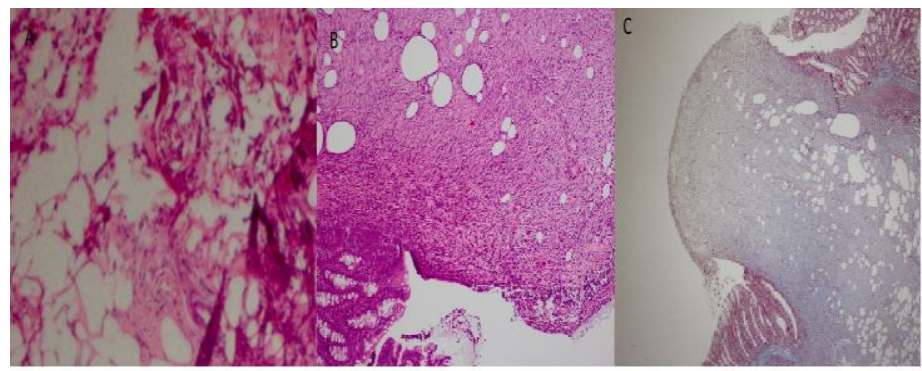

Figure 4. Histopathological appearance of the control group (H\&E x4 magnification, $\mathrm{H} \& \mathrm{E} \times 10$ magnification, trikrom $\mathrm{x} 4$ magnification).

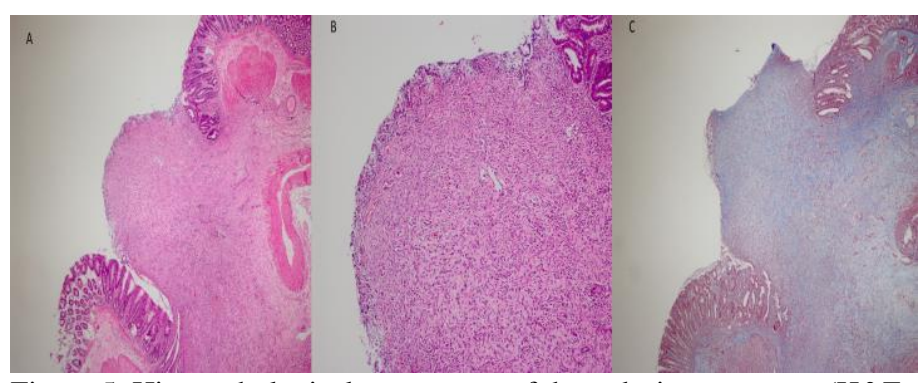

Figure 5. Histopathological appearance of the red-ginseng group (H\&E x4 magnification, H\&E x10 magnification, trikrom x4 magnification)

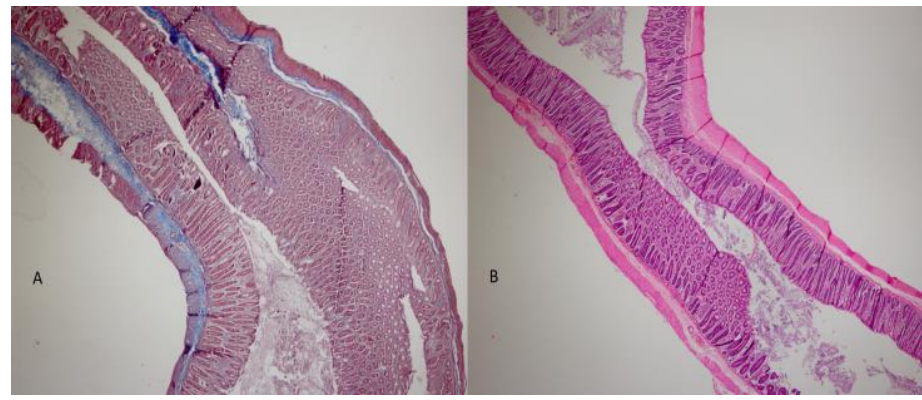

Figure 6. Histopathological appearance of sham group (H\&E x4 magnification, trikrom $\mathrm{x} 4$ magnification). 


\section{Statistical analysis}

The conformity of numerical variables to normal distribution was analyzed with the Shapiro-Wilk test. Numerical variables were given as mean \pm standard deviation or median (minimum-maximum) values and were compared with the oneway ANOVA test followed by Tukey's HSD post hoc test or the Kruskal-Wallis test followed by Tamhane's T2 post hoc test, as appropriate. A value of $p<0.05$ was considered statistically significant. Data analysis was performed using IBM SPSS Statistics for Windows, version 25.0 software (IBM Corp., Armonk, N.Y., USA).

\section{Results}

No mortality or complications occurred during the postoperative period.

The anastomotic bursting pressure values are given in Table 1. The rats in the sham group had the highest bursting pressure and the rats in the red ginseng group had higher bursting pressure than in the control group. The differences between the control group and the sham group and the red ginseng group were statistically significant $(\mathrm{p}=0.002$ and $\mathrm{p}=0.013$, respectively).

Table 2 shows the MDA, catalase, and total SH levels in the anastomosis. No significant difference was determined between the groups in respect of MDA levels. Catalase and total SH levels were significantly higher in the sham group compared to the control group ( $\mathrm{p}=0.017$ and $\mathrm{p}=0.002$, respectively), with a significant difference observed only for the total $\mathrm{SH}$ level between the control group and the red ginseng group $(\mathrm{p}=0.008)$.

The histopathological scores of the anastomosis are summarized in Table 3. The red ginseng group had the highest scores for all parameters and the differences were statistically significant compared to both the sham group and the control group. In addition, with the exception of inflammation, the control group had significantly higher scores for all the parameters compared to the sham group.

Table 1. Results and comparisons of anastomotic bursting pressure.

\begin{tabular}{cccc}
$\begin{array}{c}\text { Sham group } \\
(\text { Group 1) } \\
(\mathrm{n}=10)\end{array}$ & $\begin{array}{c}\text { Control group } \\
(\text { Group 2) } \\
(\mathrm{n}=10)\end{array}$ & $\begin{array}{c}\text { Red ginseng } \\
\text { group } \\
(\text { Group 3) } \\
(\mathrm{n}=10)\end{array}$ & $\begin{array}{c}\mathrm{P} \\
\text { Value }\end{array}$ \\
\hline
\end{tabular}

\begin{tabular}{lcccc}
\hline $\begin{array}{l}\text { Bursting } \\
\text { pressure } \\
(\mathrm{mm} \mathrm{Hg})\end{array}$ & $193.00 \pm 25.84$ & $157.50 \pm 22.72$ & $185.50 \pm 12.79$ & $0.001^{*}$ \\
& $\mathrm{p}$ & $\mathrm{p}$ & $\mathrm{p}$ & \\
& $(1-2)$ & $(1-3)$ & $(2-3)$ & \\
\hline & $0.002^{*}$ & $0.693^{*}$ & $0.013^{*}$ & \\
\hline
\end{tabular}

* One-way ANOVA test followed by Tukey's HSD post hoc test.

Table 2. Malondialdehyde, catalase, and total sulfhydryl levels in the anastomosis.

\begin{tabular}{|c|c|c|c|c|}
\hline & $\begin{array}{c}\text { Sham group } \\
\text { (Group 1) } \\
(n=10)\end{array}$ & $\begin{array}{l}\text { Control group } \\
\text { (Group 2) } \\
(\mathrm{n}=10)\end{array}$ & $\begin{array}{c}\text { Red ginseng } \\
\text { group } \\
(\text { Group 3) } \\
(\mathrm{n}=10)\end{array}$ & $\begin{array}{c}\mathrm{P} \\
\text { value }\end{array}$ \\
\hline MDA & $77.84 \pm 13.84$ & $101.66 \pm 22.72$ & $87.66 \pm 39.90$ & $0.174 *$ \\
\hline Catalase & $811.94 \pm 134.29$ & $519.35 \pm 161.88$ & $733.62 \pm 319.53$ & $0.018^{*}$ \\
\hline \multirow[t]{2}{*}{ Total SH } & $\begin{array}{c}201.06 \\
(116.53-255.36)\end{array}$ & $\begin{array}{c}118.32 \\
(83.25-130.67)\end{array}$ & $\begin{array}{c}184.08 \\
(146.72-360.22)\end{array}$ & $<0.001 * *$ \\
\hline & $\begin{array}{c}\mathrm{p} \\
(1-2) \\
\end{array}$ & $\begin{array}{c}\mathrm{p} \\
(1-3) \\
\end{array}$ & $\begin{array}{c}\mathrm{p} \\
(2-3) \\
\end{array}$ & \\
\hline MDA & $0.152 *$ & $0.711^{*}$ & $0.504 *$ & \\
\hline Catalase & $0.017 *$ & $0.710^{*}$ & $0.095^{*}$ & \\
\hline Total SH & $<0.001 * *$ & $0.002 * *$ & $0.829 * *$ & \\
\hline
\end{tabular}

MDA: Malondialdehyde, SH: Sulfhydryl, * One-way ANOVA test followed by Tukey's HSD post hoc test, ** Kruskal-Wallis test followed by Tamhane's T2 post hoc test.
Table 3. The histopathological scores of the anastomosis.

\begin{tabular}{|c|c|c|c|c|}
\hline & $\begin{array}{c}\text { Sham } \\
\text { group } \\
(\text { Group 1) } \\
(\mathrm{n}=10)\end{array}$ & $\begin{array}{l}\text { Control } \\
\text { group } \\
(\text { Group 2) } \\
(\mathrm{n}=10)\end{array}$ & $\begin{array}{l}\text { Red ginseng } \\
\text { group } \\
(\text { Group 3) } \\
(\mathrm{n}=10)\end{array}$ & $\begin{array}{c}\mathrm{P} \\
\text { value }\end{array}$ \\
\hline Inflammation & $2(2-2)$ & $3(1-4)$ & $4(3-4)$ & $<0.001 *$ \\
\hline $\begin{array}{l}\text { Fibroblastic } \\
\text { activity }\end{array}$ & $1(1-1)$ & $3(3-4)$ & $4(3-4)$ & $<0.001 *$ \\
\hline Neoangiogenesis & $0(0-0)$ & $2(2-3)$ & $3(2-3)$ & $<0.001 *$ \\
\hline \multirow{2}{*}{$\begin{array}{l}\text { Collagen } \\
\text { deposits }\end{array}$} & $0(0-0)$ & $3(2-4)$ & $4(3-4)$ & $<0.001 *$ \\
\hline & $\underset{(1-2)}{p}$ & $\begin{array}{c}\mathrm{p} \\
(1-3)\end{array}$ & $\underset{(2-3)}{p}$ & \\
\hline Inflammation & $0.360 *$ & $<0.001 *$ & $0.012 *$ & \\
\hline $\begin{array}{l}\text { Fibroblastic } \\
\text { activity }\end{array}$ & $<0.001^{*}$ & $<0.001 *$ & $0.015^{*}$ & \\
\hline Neoangiogenesis & $<0.001 *$ & $<0.001 *$ & $0.015^{*}$ & \\
\hline $\begin{array}{l}\text { Collagen } \\
\text { deposits }\end{array}$ & $<0.001^{*}$ & $<0.001 *$ & $0.034^{*}$ & \\
\hline
\end{tabular}

* Kruskal-Wallis test followed by Tamhane's T2 post hoc test.

\section{Discussion}

The findings of this study show that red ginseng has positive effects on anastomosis healing. In the group applied with red ginseng, anastomotic burst pressures were higher, and this was observed to have contributed to the healing of anastomosis histopathologically.

Anastomotic leakage is still one of the main causes of morbidity and mortality in surgical patients after colorectal surgery. The incidence of anastomotic leakage varies between 1$26 \%$. Good oxygenation at all stages is important for wound healing. During the inflammatory phase, polymorphonuclear cells require oxygen to produce superoxide free radicals to kill microorganisms and avoid infection [10]. Anastomotic leakage is difficult to treat and may require relaparotomy and stoma opening. Therefore, it is most important to prevent anastomotic leakage. Numerous experimental and clinical studies have also been conducted to achieve better wound healing after colon anastomosis [11].

Burst pressure is an accurate method for the evaluation of anastomotic healing in the early period. The best known mechanical measurement methods are burst pressure, burst wall pressure and tensile strength measurement. As the burst method only assesses transmural pressure, it is closely related to the clinical situation [12]. In the current study, anastomotic burst pressure was used for anastomosis evaluation and a statistically significantly higher burst pressure was observed in the red ginseng group than in the control group.

Inflammation plays a central role in the regulation of anastomotic healing. In the inflammatory phase, white blood cells are involved in the mobilization and activation of fibroblasts and epithelial cells [13]. Chemotactic agents, cytokines and inflammatory cells are concentrated in the anastomotic area from the second postoperative day [14]. In the current study, inflammation was more common in the red ginseng group than in the sham group and control group. Collagen is an essential protein at all stages of the wound healing process. Anastomotic integrity strength is essential for complete anastomotic healing. Matrix metalloproteinase 8 (neutrophils, macrophages, and wound-side bacteria) and de novo collagen synthesis form the amount of wound collagen in the first three days of wound healing [15]. The current study result showed that the amount of collagen in the red ginseng group was higher than in the other groups.

Ginseng (Panax ginseng C.A. Meyer, root of Araliaceae) is often used as a raw material and taken orally as a traditional medicine in Asian countries. When ginseng is poured at $98-100^{\circ} \mathrm{C}$, it is called red ginseng, the main component of 
which is ginsenoside $\mathrm{Rg} 3$ and ginsenoside $\mathrm{Rb} 1$ [16]. Considering the mechanism of action of ginsenosides, anti-inflammatory effects have been proven by purifying ginsenosides. Expressions of pro-inflammatory cytokines (TNF-alpha, IL-1 and IL-6) have been shown to induce M1 and M2 polarization of macrophages or microglia while inhibiting iNOS and COX-2 enzyme expressions, which was found to be the anti-inflammatory mechanism of ginsenosides [17]. In a study by Kosmaz et al., red ginseng was given to rats that underwent splenectomy, and its antioxidant and anti-inflammatory activity was demonstrated. In that study, red ginseng was shown to have significantly reduced MDA values, which indicate intracellular oxidative stress, and significantly increased the level of catalase, an important antioxidant [18]. In another study by Durhan et al., in which oral red ginseng was evaluated in experimental occlusive jaundice, it was observed that MDA value decreased and catalase value increased [17]. However, in the current study, MDA value decreased and catalase value increased, but no statistically significant difference was observed between the control and red ginseng groups.

In conclusion, the results of this study demonstrated that rectal administration of red-ginseng increased the anastomotic burst pressure and provided histopathological improvement. Although it decreased the MDA level, which indicates oxidative stress, and increased the antioxidant catalase level, no statistically significant difference was observed. Although the positive effects are thought to be due to its antioxidant and anti-inflammatory properties, it would be appropriate to conduct more extensive studies on the subject.

\section{References}

1. Kuru S, Kismet K, Bag YM, Barlas AM, Senes M, Durak M, et. al. Does the application of Ankaferd Blood Stopper rectally have positive effects on the healing of colorectal anastomosis and prevention of anastomotic leakage? An experimental study. Biomed Pharmacother. 2017;96:968-73.

2. Barlas AM, Kuru S, Kismet K, Cavusoglu M, Bag YM, Senes M, et. al. Rectal application of argan oil improves healing of colorectal anastomosis in rats. Acta Cir Bras. 2018;33:565-76.

3. Park GH, Park KY, Cho HI, Lee SM, Han JS, Won CH, et al. Red ginseng extract promotes the hair growth in cultured human hair follicles. J Med Food. 2015;18:354-62.

4. Park KS, Park DH. The effect of Korean Red Ginseng on fullthickness skin wound healing in rats. J Ginseng Res. 2019;43:226-35.

5. Wasowicz W, Nève J, Peretz A. Optimized steps in fluorometric determination of thiobarbituric acid-reactive substances in serum: importance of extraction $\mathrm{pH}$ and influence of sample preservation and storage. Clin Chem 1993;39:2522-6.

6. Hadwan MH. Simple spectrophotometric assay for measuring catalase activity in biological tissues. BMC Biochemistry 2018;19:7.

7. Taylan E, Resmi H. The Analytical Performance of a Microplate Method for Total Sulfhydryl Measurement in Biological Samples. Turkish Journal of Biochemistry 2010;35:275-8.

8. Ehrlich HP, Hunt TK. The effects of cortisone and anabolic steroids on the tensile strength of healing wounds. Ann Surg 1969;170:203-6.

9. Philips JD, King CS, Fonkalsrud EW, Zeng H, Dindar H. Effects of chronic corticosteroid and vitamin A on the healing of intestinal anastomoses. Am J Surg 1992;163:71-7.

10. Al-Khayal K, AlWesaimer AS, Abdulla M, Ahmed R. Insulin-like Growth Factor Administration Stimulates Wound Healing on Colonic Anastomosis in Hypoxic Rat Model. Dr. Sulaiman Al Habib Medical Journal 2020;2:43-50.

11. Ekici U, Ferhatoğlu MF, Çitgez B, Uludag M. Effects of the Folk Medicinal Plant Extract Ankaferd BloodStopper on the Healing of Colon Anastomosis: An Experimental Study in a Rat Model. Sisli Etfal Hastan Tip Bul. 2019;53:154-9.

12. Aghayeva A, Benlice C, Bilgin IA, Atukeren P, Dogusoy G, Demir F, et al. The Effects of Hyperthermic Intraperitoneal
Chemoperfusion on Colonic Anastomosis: An Experimental Study in a Rat Model. Tumori Journal. 2017;103:307-13.

13. Arapoglou S, Kambaroudis A, Grivas I, Delis GA, Karkos C, Ballas K, et al. The Effect of Iloprost in the Healing of Colonic Anastomosis in Rats under Chemotherapy with Irinotecan. Chirurgia (Bucur). 2017;112:705-13.

14. Ruiz-Luque V, Parra-Membrives P, Escudero-Severín C, AguilarLuque J. Effect of Alprostadil on Colorectal Anastomoses Under Relative Ischemia. J Surg Res. 2019;236:230-7.

15. Ferhatoğlu MF, Kıvılcım T, Vural G, Kartal A, Filiz Aİ, Kebudi A, et al. Comparison of the effects of two different marinederived omega-3 fatty acid sources, krill oil, and fish oil, on the healing of primary colonic anastomoses after colectomy applied Wistar albino rat model. Ulus Travma Acil Cerrahi Derg. 2019;25:324-30.

16. Bae EA, Hyun YJ, Choo MK, Oh JK, Ryu JH, Kim DH. Protective effect of fermented red ginseng on a transient focal ischemic rats. Arch Pharm Res. 2004;27:1136-40.

17. Durhan A, Koşmaz K, Şenlikci A, Erguder E, Suleyman M, Duymus ME, et al. Does red ginseng ameliorate liver damage caused by obstructive jaundice?: an experimental study. J Health Sci Med 2021;4:233-9.

18. Koşmaz K, Durhan A, Şenlikci A, Suleyman M, Bostanci MT, Pekcici MR, et al. Evaluation of the Protective Effect of Red Ginseng on Lipid Profile, Endothelial and Oxidative Damage after Splenectomy in Rats. ACEM. 2021;6: 43-9. 